\title{
Intraluminal injection of short chain fatty acids diminishes intestinal mucosa injury in experimental ischemia-reperfusion ${ }^{1}$
}

\author{
A injeção intraluminal de ácidos graxos de cadeia curta diminui a lesão da mucosa \\ intestinal produzida por isquemia e reperfusão experimental
} \author{
José de Souza Neves ${ }^{5}$ \\ 1. Department of Surgery, Sciences School of Medicine, Federal University of Mato Grosso. \\ 2. Head Professor of the Department of Surgery, Federal University of Mato Grosso. \\ 3. MD, Department of Surgery, Federal University of Mato Grosso. \\ 4. Medical students, Federal University of Mato Grosso. \\ 5. Assistant Professor, Federal University of Mato Grosso.
}

José Eduardo de Aguilar-Nascimento ${ }^{2}$, Alberto Bicudo Salomão ${ }^{3}$, Rubens Jardim Nochi Jr. ${ }^{4}$, Mariana Nascimento ${ }^{4}$,

\begin{abstract}
Purpose: Investigated the effect of intraluminal short-chain fatty acids (SCFA) on the intestinal mucosa in the presence of ischemia-reperfusion injury (IRI). Methods: Six blind sacs of the small bowel (3at the jejunum and 3 at the ileum) were created in ten Wistar rats. The lateral sacs of both bowel regions were subjected to IRI (15/15 minutes) while the medial sacs were let free to receive blood supply. In the lateral sacs, it was injected either a solution containing SCFA (butyrate, propionate and acetate) or pure saline at the bowel lumen. No fluid was injected in the medial sacs. Results: Both at the jejunum and at the ileum the score of the mucosal injury was higher in saline than in control sacs. SCFA treated sacs showed lesser score at the ileum $(\mathrm{p}=0.03)$ but were not significantly different at the jejunum $(\mathrm{p}=0.83)$ when compared with saline sacs. It was found a significant greater number of neutrophils $(\mathrm{p}<0.01)$ in the sacs treated with saline than in the other two sacs in both regions. Conclusion: SCFA protect the distal small bowel mucosa and diminishes infiltration of neutrophils to the gut lamina propria in IRI.
\end{abstract}

Key words: Ischemia. Reperfusion. short-chain Fatty Acids, Volatile. Intestine, Small. Neutrophils. Mucous, Membrane.

\section{RESUMO}

Objetivo: Investigou-se o efeito de ácidos graxos de cadeia curta (SCFA) na mucosa intestinal na presença de lesão por isquemia e reperfusão (IRI). Métodos: Foram criados seis sacos fechados no intestino delgado (três no jejuno e três no íleo) em 10 ratos Wistar. Ao sacos laterais de ambas as regiões intestinais foram submetidos a IRI (15/15 minutos) enquanto que o saco medial não sofreu interrupção do suprimento sanguíneo. Nos sacos laterais ambas as regiões injetou-se SCFA ou solução fisiológica na luz intestinal. Nos sacos mediais não se injetou nenhuma solução. Resultados: Tanto no jejuno quanto no íleo o escore de injuria da mucosa intestinal foi mais alto nos sacos tratados com solução salina do que nos controles. Os sacos que receberam SCFA apresentaram menor escore inflamatório no íleo $(\mathrm{p}=0.03)$ porém sem diferença no jejuno ( $\mathrm{p}=0.083$ ) quando comparados com os sacos injetados com solução salina. Observou-se um significante maior acumulo de neutrófilos nos sacos tratados com solução salina $(\mathrm{p}<0.01)$ do que nos outros dois sacos em ambas as regiões. Conclusão: Os SCFA protegem a mucosa intestinal distal e diminuem o acumulo de neutrófilos na lamina própria após IRI.

Descritores: Isquemia, Reperfusão. Ácidos Graxos Voláteis. Intestino Delgado. Neutrófilos. Membrana Mucosa.

\section{Introduction}

The intestinal mucosa is highly sensible to ischemic injury. In addition, reperfusion may increase the primary lesion promoting further tissue damage ${ }^{1}$. Mortality rate in this condition is usually high and even when bowel ischemia is under control, death may occur due to multiple organ failure $^{2}$. The mechanisms involved during ischemiareperfusion injury (IRI) are complex and seems to be mediated by reactive oxygen metabolites followed by priming and activation of polymorphonuclear neutrophils
$(\mathrm{PMN})^{1}$. In brief, large amounts of xanthine dehydrogenase are converted to xanthine oxidase during ischemia by a calcium-dependent proteolytic process. Superoxide, hydrogen peroxide, and hydroxyl radical are formed and may then cause mucosal injury both by direct action and by secondary activation of $\mathrm{PMN}^{1,3}$. Other consequence of the ischemic bowel injury is the disruption of the gut mucosal barrier predisposing the egress of harmful microorganisms and/or their toxins in a phenomenon called bacterial translocation. In fact, intestinal permeability seems to be increased during experimental $\mathrm{IRI}^{4}$. Nutritional 
solutions may have a role in IRI. Glutamine, the most abundant amino acid in blood, is the preferred fuel for the enterocyte and seems to prevent intestinal mucosal damage and enhance neutrophils function in critical illness and trauma ${ }^{5}$. The presence of glutamine may maintain glutathione levels during experimental IRI ${ }^{6}$. Glutathione is an important intracellular scavenger and its synthesis is dependent on the presence of glutamine. In the rat model, most of the oxidized glutathione is generated during ischemia rather than reperfusion ${ }^{7}$. We have previously demonstrated that intraluminal glutamine protects the mucosal injury due to IRI in rats $^{8}$. Butyrate, propionate and acetate, the most important short chain fatty acids (SCFA) are the best fuel for the colonocyte but can be used by the enterocyte as substrate ${ }^{9}$. Indeed, amounts of SCFA are absorbed and metabolized in distal small bowe ${ }^{10}$. SCFA may also stimulate the microcirculation in the human rectum ${ }^{11}$. Therefore, it seems plausible to hypothesize that the absorption of SCFA at the intestinal lumen may protect the gut mucosa from the deleterious effects of IRI or at least, decelerate the evolution of the process. Thus, the aim of this study was to investigate the effect of intraluminal SCFA on the intestinal mucosa in the presence of ischemia-reperfusion injury.

\section{Methods}

Ten Wistar rats obtained from the University of Mato Grosso Central Animal Laboratory were firstly admitted to laboratory environment three days prior to the experiment in $12 \mathrm{~h}$ cycles of light/dark in a constant room temperature of $25^{\circ} \mathrm{C}$. They were submitted under general anesthesia with intraperitoneal injection of thiopental $(30 \mathrm{mg} / \mathrm{kg})$ to a $4 \mathrm{~cm}$ median laparotomy. All animals breathe spontaneously during all the procedure. The experiment follows the COBEA (Brazilian Committee on Experimental Animal Care) guidelines adopted by the Federal University of Mato Grosso. The whole intestine was exposed and then a six $\mathrm{cm}$ long segment of the proximal jejunum, five $\mathrm{cm}$ below the duodenal jejunal angle was isolated to create three blind compartments of the gut by loosely tying four 3-0 cotton occlusive ligatures through avascular breaches of the mesentery. The same procedure was performed in an ileal segment five $\mathrm{cm}$ proximal to the ileocecal valve. The length of each sac was approximately two $\mathrm{cm}$ and they were identified as segments $\mathrm{J} 1, \mathrm{JC}$ and $\mathrm{J} 2$ at the jejunum and segments I1, IC and I2 at the ileum (Figure 1, A and B).

Both at the created jejunum and at the ileum segments, the mesenteric vessels destining to the two lateral sacs (J1, $\mathrm{J} 2$, I1 and I2) were occluded with noncrushing vascular clamps to promote ischemia for 15 minutes while the medial sacs (JC and IC) were let free to receive blood supply. At both segments $\mathrm{J} 1$ and I1, immediately after clamping the mesenteric vessels, 1-2 mL of a solution containing SCFA (Sigma-Aldrich, USA; composition: sodium acetate, $60 \mathrm{mM}$; sodium propionate, $30 \mathrm{mM}$; and sodium butyrate $40 \mathrm{mM}$; osmolarity $=280 \mathrm{mOsm} / \mathrm{L} ; \mathrm{pH}=7$ ) was injected at the bowel lumen just to fill the sac, caring to avoid over distension. All injections were done with a syringe and a small bore needle at the antimesenteric border. This composition is approximately what is found at cecal lumen. At segments J2 and $\mathrm{I} 2$, the same procedure was done using only saline.

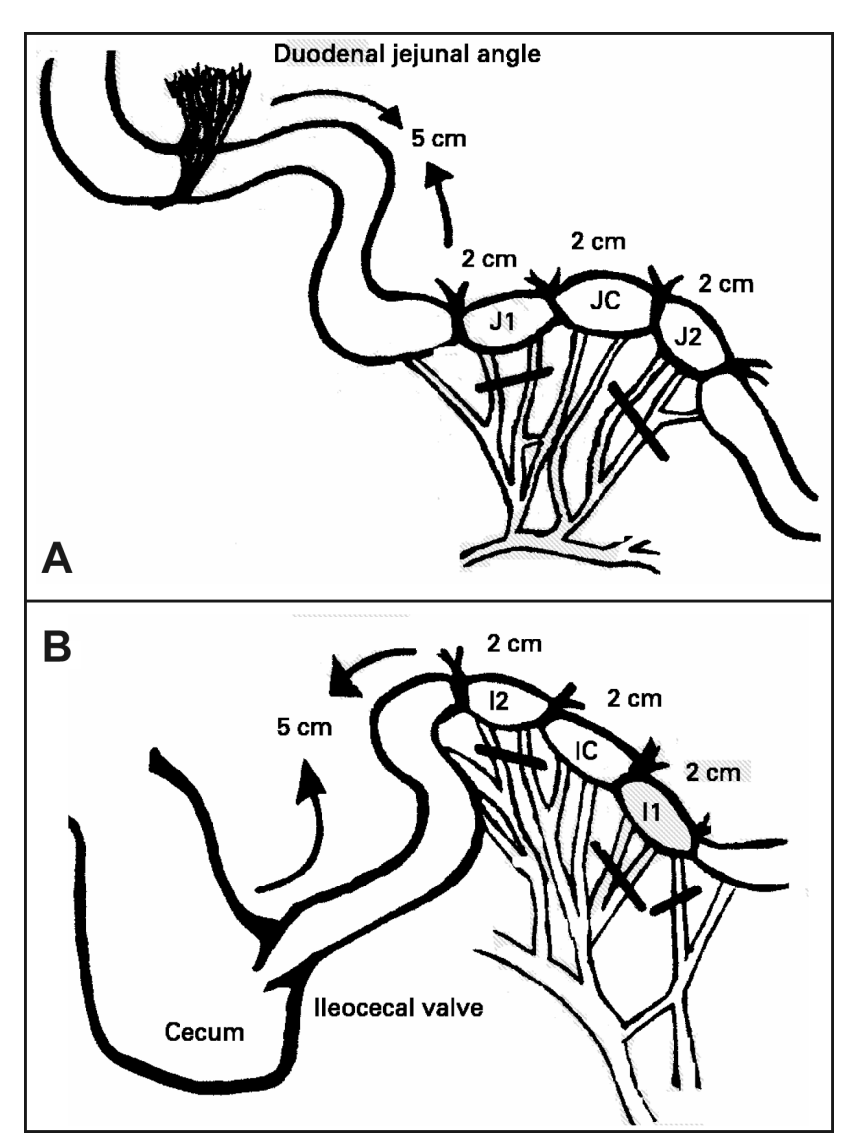

FIGURE 1 - Isolated intestinal segments at the jejunum (A) and at the ileum (B) and position of the vascular clamps.

No fluid was injected in sacs JC and IC. The clamps were then removed followed by 15 minutes of intestinal reperfusion. After that, the jejunal and ileal segments were excised, rinsed in ice-cold water and opened longitudinally. The rats were then killed by an overdose of inhalatory ether. The specimens were preserved at $4{ }^{\circ} \mathrm{C}$ until full thickness punches of total intestinal wall were obtained from the midportion of the six sacs in all animals. The specimens were immediately stored in 10\% formaldehyde and sent for microscopy analysis. At optical microscopy, hematoxylineosin stained slides cut sagitally to the serosa were analyzed by an independent observer blind to the groups, to grade the mucosal lesion according to the Chiu's system ${ }^{12}$. In summary, a score varying from zero to five was attributed to each slide to express the crescent severity of the ischemic mucosal injury (Table 1). The mean number of neutrophils counted at the lamina propria in five randomly and nonconsecutive fields in each slide (400X magnification) was registered. One-way analysis of variance (number of neutrophils per field) or the Kruskal-Wallis's test (Chiu's score) followed by Tukey's test or LSD was used to compare the data. A 5\% level was established for significance $(\mathrm{p}<0.05)$. Data were expressed as mean $\pm \mathrm{SD}$ or median (range) as appropriate. 
TABLE 1 - Classification score of the ischemic mucosal damage (Chiu et al.,1970

\begin{tabular}{c|l}
\hline GRADE & CARACTHERISTICS \\
\hline 0 & Mucosa with normal villi \\
\hline 1 & $\begin{array}{l}\text { Developing of the sub-epithelial Gruenhagen's space, usually at the villus apex, frequently } \\
\text { associated with capillary congestion }\end{array}$ \\
\hline 2 & Extension of the sub-epithelial space with moderate lifting of epithelial layer from the lamina propria \\
\hline 3 & Massive epithelial lifting down the sides of the villi \\
\hline 4 & $\begin{array}{l}\text { Denuded villi with lamina propria and dilated capillaries exposed. } \\
\text { Increased cellularity of lamina propria may be noted }\end{array}$ \\
\hline 5 & Digestion and disintegration of lamina propria; hemorrhage and ulceration \\
\hline
\end{tabular}

\section{Results}

Both at the jejunum $($ control $=2[0-4] ;$ saline $=3[1-4])$ and at the ileum segments (control $=2[0-4]$; saline $=4[1-$ $5]$ ), the attributed score of the mucosal injury was higher in the saline sac than in control sacs $(\mathrm{p}=0.02$ for both jejunum

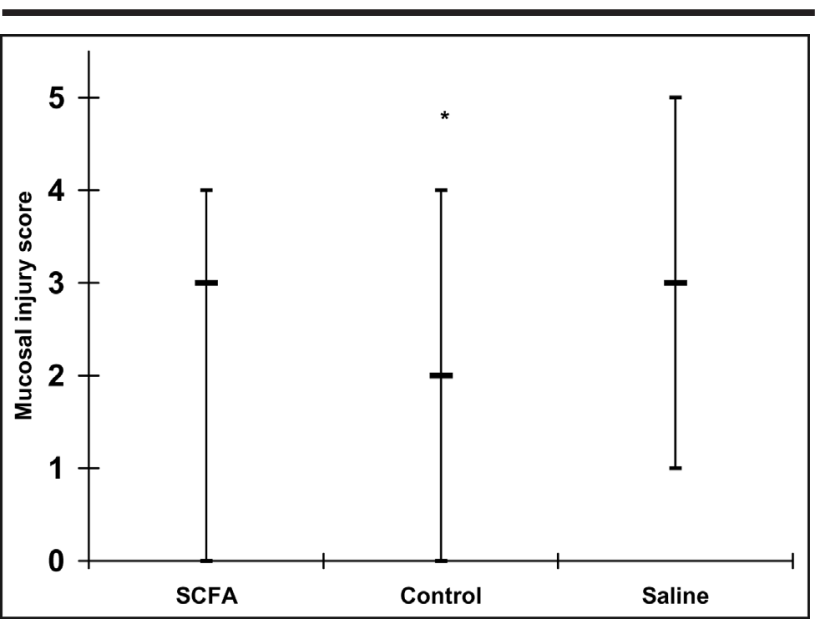

FIGURE 2 - Median (range) of the mucosal injury score at the jejunum in the three sacs. *, $\mathrm{P}=0.02$ vs. saline.

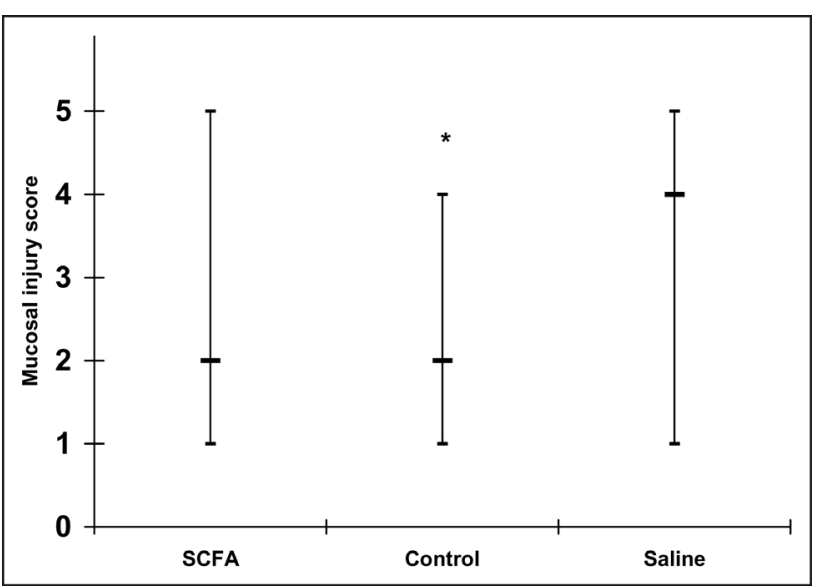

FIGURE 3 - Median (range) of the mucosal injury score at the ileum in the three sacs. * $\mathrm{P}=0.02$ vs. saline, †P $=0.03$ vs. saline. and ileum comparisons). No statistical difference occurred between SCFA (jejunum = 3 [0-4], ileum $=2$ [1-5]) and control sacs at both the jejunum $(\mathrm{p}=0.06)$ and ileum $(\mathrm{p}=0.55)$ sites. The SCFA treated sacs showed lesser score at the ileum $(p=0.03)$ but were not significantly different at the jejunum $(\mathrm{p}=0.83)$ when compared with saline sacs (Figures 2 and 3$)$.

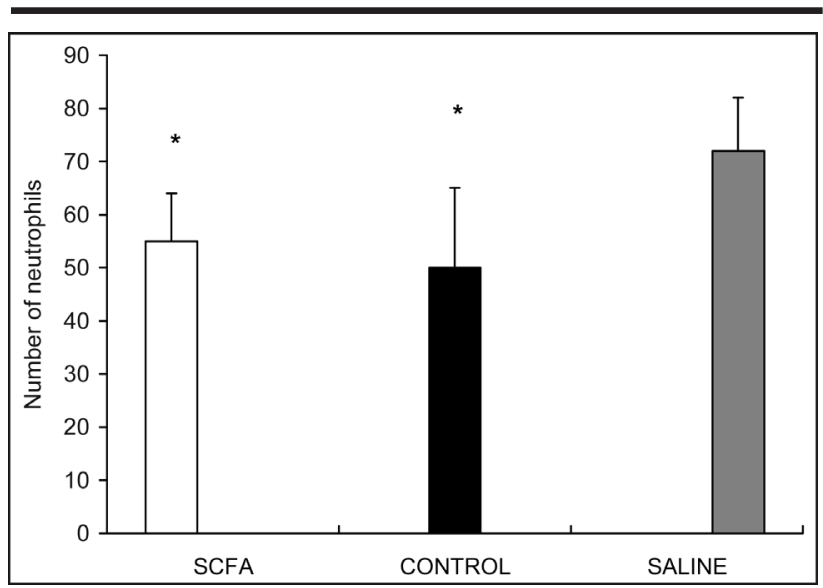

FIGURE 4 - Mean \pm SD number of neutrophils per microscopic field counted at the lamina propria at the jejunum in the three sacs. *, $\mathrm{P}<0.01$ vs. saline.

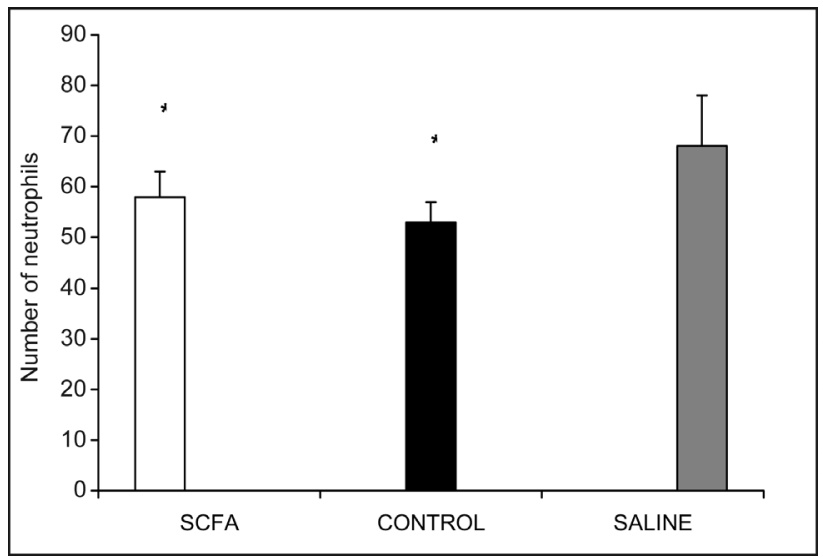

FIGURE 5 - Mean \pm SD number of neutrophils per microscopic field counted at the lamina propria at the ileum in the three sacs. *, $\mathrm{P}<0.01$ vs. saline. 
The comparison among the mean number of neutrophils per field among the sacs in the two intestinal segments can be seen in Figures 4 and 5. In both segments, the mean number of neutrophils was similar in SCFA(jejunum $=55 \pm 9$; ileum $=58 \pm 5$ neutrophils per field) and control sac (jejunum $=50 \pm 15$; ileum $=53 \pm 4$ neutrophils per field). However, neutrophils were significantly more frequent in the saline sacs at both the jejunum $(72 \pm 10$ neutrophils per field) and ileal ( $68 \pm 10$ neutrophils per field) segments when compared with the other two sacs $(p<0.01)$.

\section{Discussion}

Our findings consistently showed that the presence of intraluminal SCFA has improved not only the mucosal damage at the ileum but also the inflammatory reaction assessed by the presence of PMN at the lamina propria in both segments. It implies that SCFA, if disposable at the lumen may protect the gut mucosa from the IRI especially in distal sites of the small bowel. These findings were also consistent with the use of intraluminal glutamine as published earlier suggesting that nutritional solutions may play a role in diminishing the repercussion of IRI $I^{8,13}$. The model used in this experiment had the advantage of evaluate solutions in the same animal providing best judgment to meet the goals of the study. Moreover, the presence of a control sac continuing to receive blood supply was important for the comparisons as well. There is no consensus in the literature on how the injury followed by ischemiareperfusion of the gut should be graded. However, it is common to assess the IRI by histological evaluation ${ }^{12,14,15}$. Many systems of histological grading have been reported but it seems that the Chiu's system is reliable, has been sufficiently validated and is most suitable to be used..$^{15}$ In this animal model, it was considered 15 minutes of ischemia followed by 15 minutes of reperfusion. A limitation for this study is the time used to promote ischemia and reperfusion because it might not adequate to let the injuries occur. As no other paper has reported the effect of intraluminal injection of SCFA during IRI, further investigations are necessary to clarify if this period of time was suitable for an appropriate absorption and protection conferred by the SCFA to the mucosa. This would be important to explain the diminished mucosal injury at the ileum promoted by SCFA injection found in this study. Neutrophils seem to play an important role in the IRI. During the evolution of IRI, oxidant-induced degranulation of mast cells is followed by the recruitment of PMN (mostly neutrophils) from the bloodstream to the gut. Many inflammatory mediators such as cytokines, platelet-activating factor, leukotrienes and histamine are promptly released by the mast cells ${ }^{16}$. Another event that takes place in IRI is the upregulation of endothelial adhesion molecules, particularly P-selectin. This upregulation results in a sticky endothelium, prone to PMN adhesion. Polymorphonuclear neutrophils can potentially damage the gut mucosa via the oxidative burst phenomenon and the liberation of metalloproteins that include elastase and myeloperoxidase ${ }^{1,17}$. Interventions directed at either depleting PMN with anti-neutrophil serum or preventing leukocyte adhesion attenuate the tissue damage ${ }^{18}$. All these physiologic derangements lead to organ dysfunction that is characterized by an increased mucosal permeability. Consequently, bacterial translocation and multiple system organ failure may occur ${ }^{19}$. In this paper it was not evaluated either the occurrence of bacterial translocation or inflammatory mediators. Although this information would be of some interest, we have attained to the aim of the study and investigated only the intensity of injury at the mucosa and the accumulation of neutrophils. The oxygen metabolites produced during ischemia-reperfusion may determine cell injury by directly reacting with the polyunsaturated fatty acids of the cell membrane leading to cell death ${ }^{20}$. In this context, SCFA has been used and in fact improved the evolution of cases of ischemic colitis ${ }^{21}$. Moreover, intraluminal SCFA has enhanced colonic anastomosis that was performed in the presence of ischemia $^{22}$. Another potential application of SCFA is during the preparation of intestinal graft for transplantation. Since there is no preservation solution specifically designed for storage of small bowel grafts, the use of either glutamine ${ }^{23}$ or SCFA as nutritional solutions aiming to maintain the structure and function of intestinal grafts could be interesting for the success of the transplantation. Furthermore, SCFA may decrease bacterial translocation in rats $^{24}$. Bacterial translocation of enteric organisms is the major cause of sepsis in patients undergoing small bowel transplantation ${ }^{25}$. However, the actual role of SCFA in this ischemia-reperfusion environment demands questions that urge to be answered in further studies. The results of this experiment suggest that the presence of intraluminal SCFA is effective in diminishing or delaying the mucosal damage during ischemia-reperfusion. Although this was not entirely detected at the jejunum, the findings in distal small bowel were most evident. This could be essential in many circumstances and may save time when ischemia is reversible. Although the findings of an experimental study should be transposing to the clinical setting with caution, we conclude that intraluminal SCFA protects the distal small bowel mucosa and diminish the approach of neutrophils at the gut lamina propria in IRI.

\section{References}

1. Kong SE, Blennerhassett LR, Heel KA, McCauley RD, Hall JC. Ischemia-reperfusion injury to the intestine. Aust N Z J Surg. 1998; 68:554-61.

2. de Perrot M, Liu M, Waddell TK, Keshavjee S. Ischemiareperfusion-induced lung injury. Am J Resp Crit Care Med. 2003;167:490-511.

3. Parks DA, Williams TK, Beckman JS. Conversion of xanthine dehydrogenase to oxidase in ischemic rat intestine: a reevaluation. Am J Physiol. 1998; 254:G768-4.

4. Grotz MR, Deitch EA, Ding J, Xu D, Huang Q, Regel G. Intestinal cytokine response after gut ischemia: role of gut barrier failure. Ann Surg. 1999; 229:478-86.

5. Saito H, Furukawa S, Matsuda T: Glutamine as an immunoenhancing nutrient. J Parenter Enteral Nutr. 1999; 23(5 Suppl):S59-61.

6. Harward TRS, Coe D, Souba WW, Kingman N, Seeger JM. Glutamine preserves gut glutathione levels during intestinal ischemia/reperfusion. J Surg Res. 1994; 56:351-5.

7. Gibson DD, Brackett DJ, Squires RA et al. Evidence that 
the large loss of glutathione observed in ischemia/ reperfusion of the small intestine is nor due to oxidation to glutathione disulfide. Free Radic Biol Med. 1993; 14:427-33.

8. Aguilar-Nascimento JE, Gurgel Marques C, Carvalho Mariano A, Bicudo Salomão A, de Souza Neves J. Benefits of intraluminal injection of glutamine for intestinal mucosa during ischemia-reperfusion. Eur Surg Res. 2003; 35:352-6.

9. Roediger WE, Millard S. Colonocyte metabolism. Gut. 1996; 38:792-3.

10. Schmitt, MG, Soergel H, Wood CM, and Steff JJ. Absorption of short-chain fatty acids from the human ileum. Am J Dig Dis. 1977; 22: 340-7.

11. Mortensen FV, Jorgensen B, Christiansen HM, SlothNielsen J, Wolff B, Hessov I. Short-chain fatty acid enemas stimulate plasminogen activator inhibitor-1 after abdominal aortic graft surgery: a double-blinded, placebo-controlled study. Thromb Res. 2000; 98:361-6.

12. Chiu C, McArdle AH, Brown R, Scott HJ, Gurd FN; Intestinal mucosal lesion in low-flow states. Arch Surg 1970; 101:478-83.

13. Kozar RA, Schultz SG, Bick RJ, Poindexter BJ, DeSoignie R, Moore FA. Enteral glutamine but not alanine maintains small bowel barrier function after ischemia/reperfusion injury in rats. Shock. 2004; 21:433-7.

14. Gangadharan SP, Wagner RJ, Cronenwett JL. Effect of intravenous glucagon on intestinal viability after segmental mesenteric ischemia. J Vasc Surg. 1995; 21:900-8.

15. Quaedackers JSLT, Beuk RJ, Bennet L, Charlton A, Egbrink MGA, Jun AJ, Heineman E. An evaluation of methods for grading histologic injury following ischemia/ reperfusion of the small bowel. Transplant Proc. 2000; 32:1307-10.
16. Kanwar S, Kubes P. Mast cells contribute to ischemiareperfusion-induced granulocyte infiltration dysfunction. Am J Physiol. 1994; 267:G316-21.

17. Granger DN. Role of xanthine oxidase and granulocytes in ischemia-reperfusion injury. Am J Physiol. 1988; 255:H1269-75.

18. Kubes P, Hunter J, Granger DN. Ischemia/reperfusioninduced feline intestinal dysfunction: importance of granulocyte recruitment. Gastroenterology. 1992; 103:807-12.

19. Zhi-Yong S, Dong YL, Wang XH. Bacterial translocation and multiple system organ failure in bowel ischemia and reperfusion. J Trauma. 1992; 32:148-53.

20. Schoenberger $\mathrm{MH}$, Berger HG. Oxygen radicals in intestinal ischemia and reperfusion. Chem Biol Interact. 1990; 76:141-61.

21. Mortensen FV, Hessov I, Rasmussen A. Ischemic colitis treated with short chain fatty acids: report of two cases. J Gastroenterol. 1996; 31:302-3.

22. Topcu O, Karaday K, Kuzu MA, Ulukent S, Erkek B, Alacayir I. Enteral and intraluminal short-chain fatty acids improves ischemic left colonic anastomotic healing in the rat. Int J Colorectal Dis. 2002; 17:171-6.

23. Lew JI, Zhang W, Koide S, Smith RJ, Rombeau JL. Glutamine improves cold-preserved small bowel graft structure and function following ischemia and reperfusion. Transplant Proc. 1996; 28:2605-6.

24. McAndrew HF, Lloyd DA, Rintala R, van Saene HK. Intravenous glutamine or short-chain fatty acids reduce central venous catheter infection in a model of total parenteral nutrition. J Pediatr Surg. 1999; 34:281-5.

25. Cicalese L, Sileri P, Green M, Abu-Elmagd K, Kocoshis $\mathrm{S}$, Reyes J: Bacterial translocation in clinical intestinal transplantation. Transplantation. 2001; 71:1414-7.

\section{Correspondence:}

Dr. José Eduardo de Aguilar-Nascimento

Rua Estevão de Mendonça, 81/ 801

78045-200 Cuiabá - MT - Brazil

Phone: (55 65)623-4020

Fax:(55 65)624-7149

aguilar@cpd.ufmt.br
Conflict of interest: none

Financial source: none

Received: September 10, 2005

Review: October 18, 2005

Accepted: November 08, 2005

\section{How to cite this article:}

Aguilar-Nascimento JE, Salomão AB, Nochi Jr RJ, Nascimento M, Neves JS. Intraluminal injection of short chain fatty acids diminishes intestinal mucosa injury in experimental ischemia-reperfusion. Acta Cir Bras. [serial on the Internet] 2006 Jan-Feb;21(1). Available from URL: http:/www.scielo.br/acb 